\title{
境界要素法による磁界解析と等価磁気回路による ステッピングモータの特性算定法
}

\author{
正員 田倉 敏 靖 (東京電気) \\ 正員小貫 天（早初田大）
}

\section{1.はじめに}

最近OA 機器へのステッピングモータの応用例が 著しく増加し, 高トルク, 高速化などの性能向上も影 著であるが，理論的な設計方針についてはまだ不十分 で，試作による試行錯俁が繰返されている。

ステッピングモータのトルク算定や動特性の計算結 果に基づき，歯形形状や磁気回路の最適設計を行むう とする場合，モータの全領域にわたる磁界解析が容易 に行えるなら理想的である。しかし，特にハイブリッ ド形ステッピングモータの場合は，他の多くの回転機 が奥行き方向に同一構造で，その任意一断面に関する 二次元として考察できるものであるのとは異なり，三 次元構造として処理しなければならないので, モータ 全領域にわたる磁界解析は現状の大形コンピュータを もってしても実現不可能である。そこで, 著者らは二 次元磁界解析によってモー夕の局部的な定数を求め, それらを三次元の全体的な等価磁気回路に適用すると いう手段を提案するものである。

現在, 各種モータの数值解析法として有限要素法に よる論文は多数発表されているが(1) (3)，これらの手 法をステッピングモータに適用しようとすると、コン ピュータの容量不足や計算時間の制限, 入力時間の手 数, 定式化の困難さなどの多くの問題に遭遇する。

そこで著者らは，まずエアギャップ設計の第一段階 として, 基本的な特性を道くため, 周期境界条件を考 虑した 0-1 次境界要素を磁極の小歯極部 1 ピッチ間に

A Calculation Method of Characteristics of Stepping Motor Using Magnetic Equivalent Circuit and Magnetic Field Analysis of Boundary Element Method. By Toshiyasu Takura, Member (Motor Engineering Department, Tokyo Electric Co., LTD.) \& Takashi Onuki, Member (Faculty of Electrical Engineering, Waseda University).

田狊敏靖: 正員, 東京電気(株)モ一夕技術部

小貫天: 正員, 早船田大学理工学部電気工学科
適用し，各種齿形の相逢によるスティフネス特性の茬 を解析し雨形設計に活用した ${ }^{(4)}$ 。境界要菜法 (BEM) による解析は有限要素法 (FEM) と異なり， モータトルクがロータとステータ間の角度 $\theta$ の関数 として極めて簡単に算定でき, 流束が内点の任意の点 で直接高精度に求められる利点があるので,この流束 を利用したトルク算定法も精度が高いと予想され，相 パーミアンスの算定には最も適していると思われる。 BEM は領域問題を境界問題に置き換えるので, その 結果，要素分割の数が少なくでき，境界形状の変化に 対する計算も簡単となる。更に，内部点における物理 量の微分值，例えば磁束密度は，FEM などが離散化 愦差を含む数值的手法を用いるのに反し，理論的な方 法によって導かれる。ただし，解析対象の媒体が不均 一であったり非線形となる場合 BEM ては表現が困難 となる。今回の解析対象はロータとステータの刘向す る磁気歯部ギャップ部であり，その解析する形状が 時々刻々と変化するので, BEM が非常に有効である と言える。そこで著者らは，エアギャップ全体の磁束 変化によるトルク算定法と，エアギャップ中央部を貫 く面を介するマクスウェル応力による算定法を比較検 討してみた ${ }^{(5)}$ 。トルク算定結果は両者よく一致した が，それぞれに利点と欠点があるので目的に応じた使 い分けを行うことが有効であると思われる。

続いて磁気回路最適設計のための第二段階として， モータ全体にわたる三次元解析を試みたが, 前述した 理由により至難であったので, 全体的な磁束分布には その流れを適切に記述した等価磁気回路を導入し, そ の回路の特に重要な要因となるエアギャップ周辺に関 しては局部的な磁界解析を行う“場”の解析と“回 路”の処理を並行して行う混合手法を開発した ${ }^{(6)}$ 。

この混合手法では，“場”の解析にあたり，霜部礠 界の周期性に着眼し BEMによる解析を行っている が,この BEM による解析により FEM に比べ次のよ 
うな効果が得られている。この手法において必要とな るエアギャップパーミアンスの計算は，ローターステ 一夕間の相対変位 $\theta$ に応じ数多くの繰返し計算が必 要となるのて，FEMによる処理ては計算時間の制限 や入力の手間のため, 磁気回路の最適化情報を得る道 具として十分活用することができない状況にあった。 しかし，このBEM を応用した混合手法では解析時間 が短縮され，歯形やマダネットの変更による動特性の 変化も容易に算定できるものとなった。

本論文ては，まずステッピングモータ菌部への境界 要素離散化法の適用法について述べ, 続いて等価磁気 回路の導入による磁気回路マトリックス方程式の等出 を行う。更に，第 4 章では BEMによる相パーミアン ス決定法について述へ，第 5 章で設計法の第三段階と して，トルク算定法と動特性解析法について述へる。 最後に本手法によって得られたスティフネス特性, 動 特性の解析結果を実験結果と共に示し,この手法の有 用性を実証する。

\section{0-1 次境界要素法による磁界計算}

境界要素法のポテンシャル $U$ に対しては一次, そ の流束 $q$ に対しては 0 次の離散化を行う方式を磁気 㐘部の設計に試みる。ステッピングモータのエアギャ ップ小歯極配置は，一般にバーニアタイプなどの例外 はあるが，図1に示すと抢り同一形状で同一ピッチの 形状となっており, その1畨対抗部分の磁界分布は周

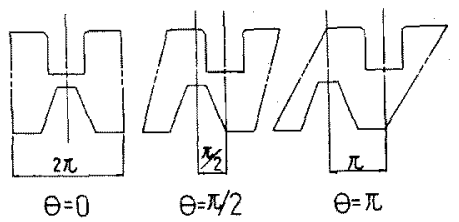

図 1 、ロー夕変位 $\theta$ とエアギャップ形状

Fig. 1. Displacement of rotor \& shape of air gaps.

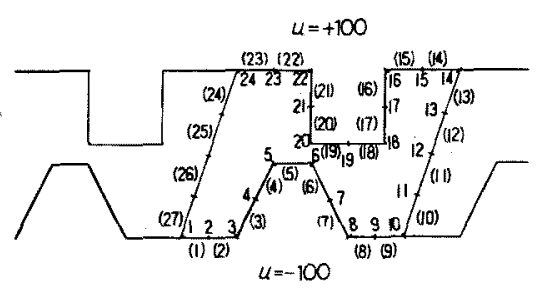

図 2 磁極間の境界要素分割

Fig. 2. Boundary element division between poles.
期的に配列しているものと見なせる。この基本的なギ ヤップ配列がロー夕変位と共に図 1 のうに変化し, モータ全体としてのトルクは $A$ 相と $B$ 相などの位相 の異なった小蔝極に発生するトルクが合成されたもの として算出できる。従って, 求めたいスティフネス特 性をもった曾形形状を容易に設計することが可能とな る。

図 2 は上下に $100 \%$ のポテンシャルが与えられ， 左右に周期境界をもつ磁極間の磁位分布を求める磁界 要索分割モデルを示したものである。同図に示すよう に境界を選び，要素分割は説明上 27 要素の分割とす る。第一種境界条件の与元られる要素 $(1) \sim(9)$, （14）（23）に対し要素中点に考察点を設けて18 個の 式を立て，周期境界要素上 (10)〜 (13)，(24)〜(27)で はポテンシャルと流束が未知のため要菜中点 8 個と要 素節点 6 個に考察点 $P$ を設け， 7 対 14 個の式を立て る。関係式は次のグリーンの公式により得られる。す なわち，ラプラス方程式を満足するポテンシャル $U$ と境界 $\Gamma$ に関する法線方向微分值 $q$ を考えると, 次 の境界積分方程式を得る。

$$
C_{p} U_{p}+\int_{\Gamma} H U d \Gamma=\int_{\Gamma} G q d \Gamma
$$

ただし， $2 \pi C_{\rho}$ ：考察点において領域を見込む角 ここで,

$$
\begin{aligned}
& H=(1 / 2 \pi)(-1 / r) \cos (r n) \\
& G=(1 / 2 \pi) \ln (1 / r)
\end{aligned}
$$

周期境界条件より左右の辺の相対応する $U$ は同じ值 となり $q$ は符号反対となるので,この 7 対の方程式 は端節点に関する対応する 3 対の式を加元, 中央節点 に関する 4 対の式を減ずることにより，7個の方程式 が得られる。結局， $U$ とqk関し次の連立方程式を 得る。

$$
[\boldsymbol{H}]\left[\begin{array}{c}
U_{1} \\
U_{2} \\
\vdots \\
U_{27}
\end{array}\right]=[\boldsymbol{G}]\left[\begin{array}{c}
q_{1} \\
q_{2} \\
\vdots \\
q_{27}
\end{array}\right] .
$$

ここて， $U_{1} \sim U_{9}, \quad U_{14} \sim U_{23}$ 怯既知, $q_{1} \sim q_{9}$, $q_{24} \sim q_{27}$ 洨末知, $U_{11}=U_{27}, U_{12}=U_{26}, U_{13}$ $=U_{25}, \quad q_{10}=-q_{27}, \quad q_{11}=-q_{26}, \quad q_{17}=-q_{25}$, $q_{13}=-q_{24}$ (末知)

左右の周期境界条件によりポテンシャルまたは流束の

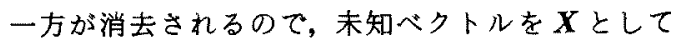
(2)式を処理すると, 次の連立方程式を得る。

$$
[\boldsymbol{A}][\boldsymbol{X}]=[\boldsymbol{F}]
$$

上式上り、ロータまたはステータの境界要素を貫く全 


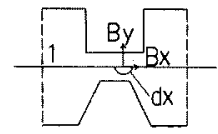

図 3 マクスウェル応力算定の境界

Fig. 3. Boundary for calculation of Maxwell's stress.

磁束を求めポテンシャルで除すことにより，ギャップ モデルのパーミアンスを求めることができる。

著者らは，さきにこの境界要素法による解析をステ イフネス特性算定に適用するにあたり，磁界エネルギ 一仮想変位の原理による算定法とマクスウェル応力に よる算定法を試み, 両者の長短を比較した。前者は磁 気的飽和を考慮しないとき適用できる算定法で, 起磁 力 $N I$ (一定) のループが作る磁束を のとしたときの 磁気随伴エネルギー $W_{m}$ が

$$
W_{m}=1 / 2 \cdot N I \Phi
$$

と書けることより, 可動方向の推力は

$$
F_{x}=d W_{m} / d x
$$

として与えられる。

後者は, 図 3 のエアギャップ中央を貫く界面を考え この界面 1 上の微少区間 $d x$ における磁束密度の $x, y$ 成分を, $B_{x}, B_{y}$ とすると, 推力 $F_{x}$ は次式により算定 できる。

$$
F_{x}=(1 / \mu) \int B_{x} B_{y} d x
$$

ただし， $\mu:$ 透磁率

両者の結果はよく一致したが, 磁界エネルギー仮想変 位の原理による算定法では単一の角度変位における推 力の算定ができないという久点があるのに対し，マク スウェル応力による算定法は内点の磁束密度計算に時 間がかかるという欠点がある(4)。本論文の手法では, 計算時間を重視し，前者の磁界エネルギー仮想変位の 原理による算定法を採用した。境界要素法の採用はス テッピングモータのように，ロータとステータの定ま つた形の相対的な動きを有する現象を解析する場合に 極めて有用である。

\section{3. 等価磁気回路の導入}

従来，ステッピングモータの等価磁気回路としては レラクタンス形が主流で，ロータにマグネットをもつ ハイブリッド形のそれは正確に表現されていなかっ た。著者らはこのマグネットの部分を考慮し，ハイブ リッド形であるために生じるニつのロータディスク相 互の関係も表現した等価磁気回路を導入する。また, 磁気パーミアンスのような重要な回路定数については

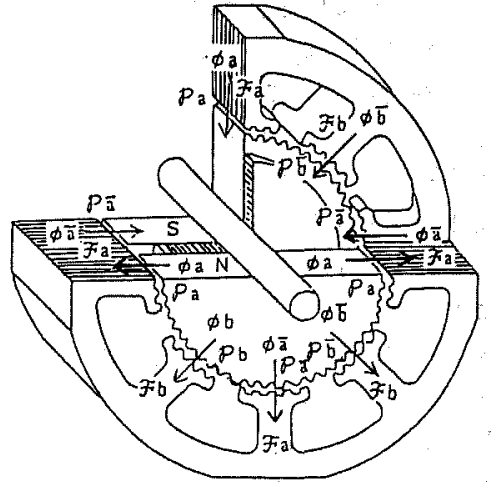

図 4 ステッピングモータ部分断面図

Fig. 4. Cutaway diagram of the stepping motor.

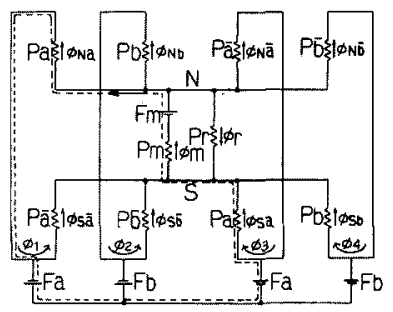

図 5 等価磁気回路

Fig. 5. Magnetic equivalent circuit of the stepping motor.

次章に述べる BEM 解析により求める。

この等価磁気回路が通常のそれと異なる点は，お互 いに相対するロータディスク間に存在する漏れ磁束を 考慮している点と，各磁極ごとに巻線と銷交せずに， $A$ 相ポールから $\bar{A}$ 相ポールの上うに漏えいする磁束 の存在を考慮している点にある。

この等価磁気回路では，ロータの $N$ 極側から $A$ 相 ポールに流れる磁束 $\Phi_{N a}$ は同ポールに巻かれた巻線 と鎖交することなくロータの $S$ 極側に戻る $\Phi_{s \bar{a}}$ の部 分と, $A$ 相ポール巻線と鎖交した後ステー夕の外周 $\exists$ ヨ部を回り, $S$ 極側にある $A$ 相ポール巻線と鎮 交し $A$ 相ギャップを通ってロータの $S$ 極側に戻る， 三次元的流れが表現されている。

考察モー夕の部分断面図を図 4 に，本モー夕の等価 磁気回路を図 5 に示す。このモータは二つのロータデ イスク間にマグネットを有するハイブリッド形ステッ ピングモータで, 基本ステップ角 $1.8^{\circ} ， 8$ ポールの モータである。本モータにはマグネットの $N$ 極と $S$ 
極側それぞれ8個，合せて16 個のエアギャップがあ る。しかし, 図 5 に示寸等価磁気回路では, 二つの同 相のエアギャップは一つにまとめて八つのパーミアン ス部分としてまとめて記述している。

ここに, $F_{m}$ 妵永久磁石の起磁力, $P_{m}$ は永久磁石 のパーミアンスとする。永久磁石の磁化曲線は一般に 非線形であるが，ステッピングモータの $N$ 極側と $S$ 極側は対称形て，どちらも $A$ 相， $B$ 相などがあり各 相パーミアンスを合成した值はほほ一定となる。従っ て，永久磁石から見たパーミアンス変化は微少である ため，隇磁曲線上の動作点での微分透磁率を考充磁化 力を求めることができる。すなわち，動作点での接線 と磁化力軸との交点として磁化力 $H_{m}$ を求め, 磁石の 厚さを乗じて起磁力 $F_{m}$ が定められる。サマリウム・ コバルト磁石やネオジウム・鉄磁石，フェライト磁石 などの場合は減磁曲線が広い範囲で真空の透磁率とほ 浔等しい直線となっているので, 線形近似で全く問題 ないが，アルニコなどの磁石で非線形の動作点で使用 する場合性使用磁石の減磁曲線を正確に把握すること が必要となる。図 5 の等価磁気回路で $A$ 相に扔ける 部分, すなわち永久磁石の $N$ 極側ロータディスクか ら $A$ 相のエアギャップを通り，A相ステータポール の营線と鎖交し, 更に $S$ 極側の $A$ 相ポール巻線と鎖 交して $S$ 極側 $A$ 相エアギャップを経て，ロータディ スクのS極側に至る同図の破線で示す経路だけを回 路的に取出して考えると, 磁気回路方程式は

$$
\Phi_{N a}+\Phi_{s a}=\left(2 \times F_{a}+F_{m}\right) \times P_{a}
$$

のようになる。同様に，この回路にキルヒホッフの法 則を適用してマトリックス形式にまとめると(8)式を 得る。

だた゚し（8)式で $N$ 極側ギャップを通る磁束をそ れぞれ， $\Phi_{N a}, \Phi_{N b}, \Phi_{N a}, \Phi_{N b}$ ，と表し，S極側ギャッ ブを通る磁束を $\Phi_{s \bar{a}}, \Phi_{s \bar{b}} \Phi_{s a}, \Phi_{s b}$ と表す。

$$
\left[\begin{array}{cccccccccc}
R_{a} & 0 & 0 & 0 & 0 & 0 & 0 & R_{b} & R_{m} 0 \\
R_{a} & 0 & 0 & 0 & 0 & 0 & R_{a} & 0 & R_{m} & \\
R_{a} & 0 & 0 & 0 & 0 & R_{\bar{b}} & 0 & 0 & R_{m} & 0 \\
R_{a} & 0 & 0 & 0 & R_{\bar{a}} 0 & 0 & 0 & R_{m} & 0 \\
R_{a}-R_{b} & 0 & 0 & 0 & 0 & 0 & 0 & 0 & 0 \\
R_{a} & 0 & -R_{\bar{a}} & 0 & 0 & 0 & 0 & 0 & 0 & 0 \\
R_{a} & 0 & 0 & -R_{\bar{b}} & 0 & 0 & 0 & 0 & 0 & 0 \\
0 & 0 & 0 & 0 & 0 & 0 & 0 & 0 & R_{m} & R_{r} \\
1 & 1 & 1 & 1 & 0 & 0 & 0 & 0 & -1 & 1 \\
0 & 0 & 0 & 0 & 1 & 1 & 1 & 1 & -1 & 1
\end{array}\right]
$$

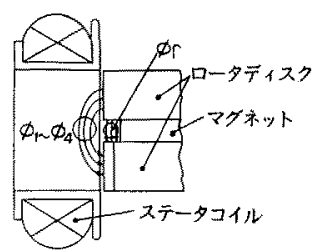

図 6 マグネット間の漏れ磁東

Fig. 6. Non-interlinked leakage flux paths with coil.

$$
\left\{\begin{array}{l}
\Phi_{N a} \\
\Phi_{N b} \\
\Phi_{N \bar{a}} \\
\Phi_{N} \\
\Phi_{s \vec{a}} \\
\Phi_{s \bar{b}} \\
\Phi_{s a} \\
\Phi_{S b} \\
\Phi_{m} \\
\Phi_{r}
\end{array}\right\}=\left\{\begin{array}{l}
F_{a}+F_{b}+F_{m} \\
2 \times F_{a}+F_{m} \\
F_{A}-F_{b}+F_{m} \\
F_{m} \\
F_{a}-F_{b} \\
2 \times F_{a} \\
F_{a}+F_{b} \\
F_{m} \\
0 \\
0
\end{array}\right\}
$$

ただし， $R: P$ の逆数（レラクタンス）

この等価磁気回路ではマグネットを等価電圧源として ではなく， $R_{m}$ という内部抵抗を含んた值として扱っ ている。また，マグネットと並列に置かれたP パーミアンスが考慮されているので，モータ動作時に おけるマグネットの動作点変化恃自動的に考慮される ことになる。エアギャップ部を通るが，ポール部巻線 と鎖交しない漏饥磁束を図 6 亿示す。これらは等価磁 気回路では $\Phi_{1} \sim \Phi_{4}, \Phi_{r}$ として与元られ，それぞれ $F_{a} や F_{b}$ を通らず $N$ 極側の $A$ 相ギャップから $S$ 極 側の $\bar{A}$ 相ギャップに直接流れる磁束と，ロータディ スク間で直接漏れる磁束を表している。ロータディス ク間隔の狭い小形モータではこの漏れ磁束は無視す ることができない重要なものとなっている。

\section{BEMによる相パーミアンスの算定}

磁気パーミアンスを求めるなど，電気機器の磁界問 題を解析する手法には，BEM のほかに有限差分法 (FDM)やFEMなどがあるが，BEM は FDMゃ FEM に比べ相パーミアンスの算定には最も適してい ると思われる。今回の解析対象位ロータとステー夕の 対向する磁気㧘部ギャップ部て，その解析する形状が 時々刻々と変化するので，BEMが非常に有効であ る。 


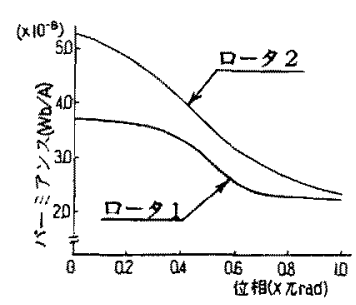

図 71 歯分のパーミアンス変化

Fig. 7. Permeance curves per one tooth pitch.

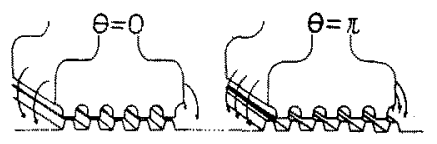

図 8 ステー夕端部の漏れ磁束

Fig. 8. Leakage flux at stator pole edge.

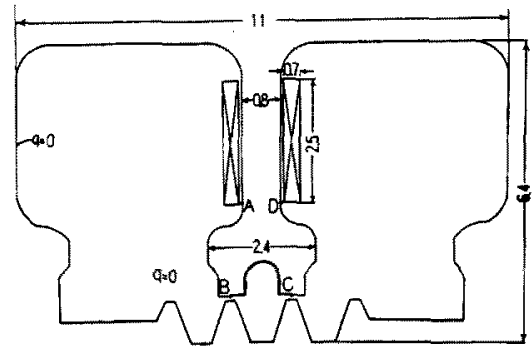

図 9 漏れ係数解析対象

Fig. 9. Analysis object of leakage flux ratio.

ロータのステータに対する変位を $\theta$ から $\pi$ まで変 化させたときの，1歯分のパーミアンス変化を図 7 に 示す。ロロタ1は菌先幅が小さい場合て、ロー夕2は 雪先幅が比較的大きい場合である。この計算では総要 素数を 180 とし，ロータとステータにそれぞれ相等し い磁荷を与え磁気異方性は無視したが，ロータとステ 一夕の歯先が局部的な対向位犆関係になった場合，一 部の要素で磁束密度が異常に大きくなり，線形解析が 成立しなくなることに対する近似として，飽和を生ず る簓所のギャップを広げる補正を行っている。実際の ステータでは既に解析した形状と同じ菌が中央に三つ 付き，合計五つの電をもつている。兩端の畨ては図 8 に示すようなロー夕の変位と共に変化する漏れ磁束が 存在する。この影響を考慮するため, 両端の雨だけを 取出し図 9 に示すような解析刘象を考える。各ステー 夕ポールには 5 対の小雨極があり，中央部の $B-C$ 間 には 4 対の小電極が配列されていると考えられるの て, 図 9 において，B-C間を通る磁束 $q(B C)$ が図 7
表 11 1ポールあたりの漏扎磁束係数 $\lambda$

Table. 1 Leakage flux ratio.

\begin{tabular}{cc|c|c|c|c|c}
\hline $\begin{array}{c}\text { 変 位 } \\
(\times \mathrm{rad})\end{array}$ & 0.0 & 0.2 & 0.4 & 0.6 & 0.8 & 1.0 \\
\hline$\lambda$ & 1.442 & 1.452 & 1.533 & 1.678 & 1.763 & 1.789 \\
\hline
\end{tabular}

のパーミアンス変化の 4 倍と同値とみなされる。A$B$ 闃と $C-D$ 間を通る磁束 $q(A B C D)$ を部算して, $q(B C)$ に対する $q(A B C D)$ を漏九磁束比 $\lambda$ として定 める。1相あたりのパーミアンスはこの淈れ磁束比 を取入れ，次式により求められる。

$$
P(\theta)=2 \times(4+\lambda) P_{i}(\theta)
$$

ただし, $P_{t}(\theta): 1$ 公分のパーミアンス変化

図 9 において，ポテンシャルには磁気ハクトルポテ ンシャルを用い電流密度を $J$ ，境界には磁束の漏れが ないと仮定し，ノイマン条件 $(q=0)$ を与える。1極 あたりの漏九磁束比 $\lambda$ 算定結果を表 1 に示す。入は 変位と共に約 1.4 加ら1.8に変化している。

ここで,P( $(\theta)$ はいかなる変化においても呼出せる ようフーリ土級数で表すと (10)式となる。

$$
\begin{aligned}
P(\theta)= & a_{0}+a_{1} \cos \theta+a_{2} \cos 2 \theta+\cdots \\
& +a_{8} \cos 8 \theta \quad \ldots \ldots \ldots \ldots \ldots \ldots \ldots
\end{aligned}
$$

\section{5. 動特性の解析}

エアギャップに蓄積される磁気エネルギーは次式の ように表される。

$$
W(\theta)=\frac{1}{2}\left(\frac{\Phi_{N a}^{2}}{P_{a}}+\frac{\Phi_{N b}^{2}}{P_{b}}+\cdots \frac{\Phi_{S \vec{a}}^{2}}{P_{\bar{a}}}+\frac{\Phi_{S \bar{b}}^{2}}{P_{\bar{b}}}\right)
$$

ロータの各位置でのトルクは(12)式により求められ る。

$$
T(\theta)=-d W(\theta) / d \theta
$$

実際には，(10)式で求めた嗞気パーミアンスの逆数を 微分した関数求わておき，(8)式から得られる磁束 の2 乗值を乗算してゆく。これによりトルク演算時間 が短縮される。

ステッピングモータの運動方程式は次式のように表 される。

$$
\begin{aligned}
& J_{0} d^{2} \theta / d t^{2}+D d \theta / d t+N_{f}=T \quad \cdots \cdots \cdots \cdots(13) \\
& \text { ここで, } J_{0}: \text { モータと負荷のモー夕軸換算人 } \\
& \text { ナーシャ, } D: \text { 粘性減衰係数, } N_{f}: \text { 負荷ト } \\
& \text { ルク }
\end{aligned}
$$

Dの算出はトルター電流特性が既知のトランジスタ モータにより供試モータを駆動し，ロータ回転速度に 対する損失トルクを求めることにより行う。この損失 
トルクは純粋な機械損のみならず，磁石の回転による 摃失も含まれたもので，回転速度に比例した関係とし て得られる。従って, この $D$ の值は各種モータタイ プ別に収集された実験值に基づいたもので，本解析の 対象としたモータでは $5.5 \times 10^{-9} \mathrm{~N} \cdot \mathrm{m} \cdot \mathrm{s} \cdot \mathrm{rad}^{-1}$ であ る。

ステッピングモータは電気と機械の結合系であるか ら，(13)式の運動方程式と次の電圧方程式との連立方 程式を解くことが必要となる。

$$
\begin{aligned}
& R_{a} i_{a}+\frac{d}{d t}\left(L_{a} i_{a}\right)+\frac{d}{d t}\left(M i_{b}\right)+K \frac{d \Phi_{a m}}{d t}=V / a \\
& R_{b} i_{b}+\frac{d}{d t}\left(L_{b} i_{b}\right)+\frac{d}{d t}\left(M i_{a}\right)+K \frac{d \Phi_{b m}}{d t}=V / b
\end{aligned}
$$

ここで, $R_{a}, R_{b}$ : コイル抵抗, $L_{a}, L_{b}:$ 自己 インダクタンス, $M:$ 相互インダクタンス,

$\emptyset_{a m}, \Phi_{b m}$ : 各励磁コイルと鎖交するマグネッ

トによる磁束，K：ステータポール励磁コイ ルとの係数

$B$ 相ポールに探りコイルを巻き， $A$ 相， $B$ 相コイ ルを励磁したとさの出力電圧を求め, 相互インダクタ ンスと自己インダクタンスを比較したところ，前者は
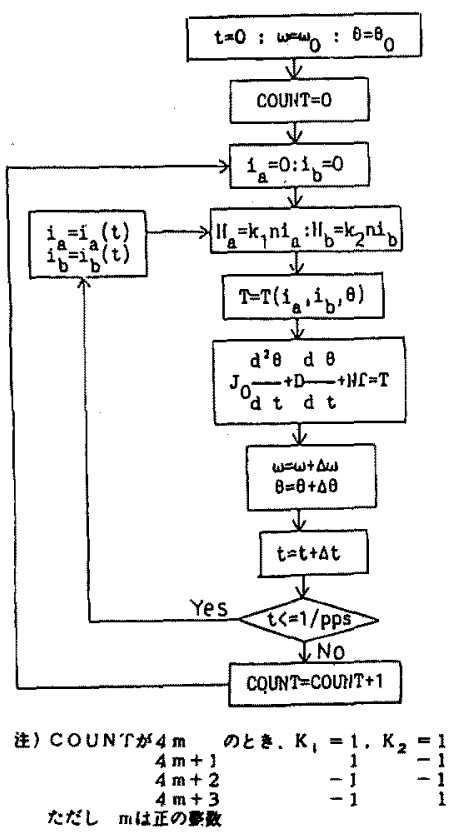

図 10 動特性算定流九図

Fig. 10. Flowchart of calculation procedure of dynamic characteristics.
後者の約 $3 \%$ に過ぎず無視できるものと言える。従っ て，(14)，(15)式は(16)，(17)式のように簡略化され る。

$$
\begin{array}{r}
R_{a} i_{a}+L_{a} \frac{d i_{a}}{d t}+i_{a} \frac{d L_{a}}{d t}+K \frac{d \Phi_{a m}}{d t}=V_{a} \\
\ldots \ldots \ldots \ldots \ldots \ldots \ldots \ldots \ldots \ldots \ldots \ldots \ldots \ldots \ldots \\
R_{b} i_{b}+L_{b} \frac{d i_{b}}{d t}+i_{b} \frac{d L_{a}}{d t}+K \frac{d \Phi_{b m}}{d t}=V_{b}
\end{array}
$$

動特性を求めるには，この(16)，(17)式と(13)式を組 合せて解けばよいが，この際(13)式は右辺のトルク $T$ が相電流および変位の関数になっているのて，ま ず(16)，(17)式より電流の立上りカーブを算出し, 得 られた電流曲線を基に微少時間ごとに相電流を等価磁 気回路のマトリックス式(8)の起励力項 $F_{a}, F_{b}$ に代 入し，各相磁束を求めると同時に(12)式よりトルクを 逐次計算していく。この得られたトルク值をモータ運 動方程式(13)式に代入しロー夕変位 $\theta$ および速度 $\dot{\theta}$ を算出する。連続応答のシミュレーションにおいて は，1パルスごとに励磁相の切換えと，コイル励磁方 向の切換えを行う。以上の流れ図を図 10 に示す。

\section{6. 解析結果の検証}

〈6・1〉無励磁時のポール磁束 磁気回路方程式 (8) より $\Phi_{a}(\theta=0), \Phi_{\bar{a}}(\theta=\pi)$ を求める。無励磁のた め $F_{a}, F_{b}$ 注短絡して考元， $F_{m}, P_{m}, P_{r}$ はマグネット の外形, 厚さ，保磁力より求めるが，その結果を表 2 に示す。

これらの值を(8)式に代入し， $A$ 相， $\bar{A}$ 相の磁束 を求める。ロー夕 1 の場合 $\Phi_{a}=2.717 \times 10^{-5} \mathrm{~Wb}, \Phi_{\bar{a}}$ $=1.698 \times 10^{-5} \mathrm{~Wb}$ ，ロー夕 2 の場合 $\Phi_{a}=2.395 \times 10^{-5}$ $\mathrm{Wb}, \Phi_{\bar{a}}=0.957 \times 10^{-5} \mathrm{~Wb}$ を得る。それぞれ $1 / 2 \times\left(\Phi_{a}\right.$ 一 $\left.\oplus_{\bar{a}}\right)$ の值注, $5.1 \times 10^{-6} \mathrm{~Wb}, 7.15 \times 10^{-6} \mathrm{~Wb}$ である。 一方，1ポールに巻いた探りコイルによる実測值は口 一夕1の場合 $5.0 \times 10^{-6} \mathrm{~Wb}$ ， ロータ2 2 場合 $7.2 \times$ $10^{-6} \mathrm{~Wb}$ となり, 実験結果と極めて良い一致が得られ た。これは、この等価回路が適正であることを示して

\begin{tabular}{|c|c|c|c|c|c|}
\hline & $\begin{array}{l}\text { マグネット } \\
\text { 外径10-3 }\end{array}$ & $\begin{array}{l}\text { マグネット皁 } \\
\Xi \times 10^{-3} \mathrm{~m}\end{array}$ & $\begin{array}{c}F_{m} \\
\times 10^{2} \mathrm{~A}\end{array}$ & $\begin{array}{c}P_{m} \times 10^{-7} \\
\mathrm{~Wb} / \mathrm{A}\end{array}$ & $\begin{array}{c}P_{x} \times 10^{-7} \\
\mathrm{~Wb} / \mathrm{A}\end{array}$ \\
\hline$\square-\not>1$ & 16.7 & 1 & 6.40 & 2.25 & 1.80 \\
\hline$\square-\not 2$ & 20 & 2 & 4.00 & 1.85 & 2.0 \\
\hline
\end{tabular}
いる。

表 2 ポール磁束算出の諸定数

Table 2. Constants in calculation of pole flux. 


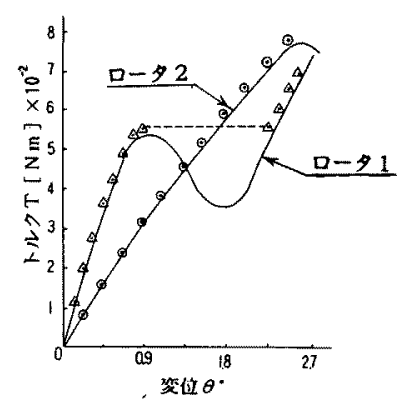

図 11 二相励磁のスティフネス特性

Fig. 11. Stiffness at two phase excitation.

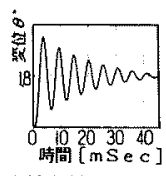

(1) 解析转果

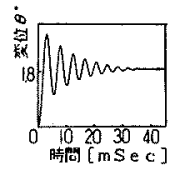

(口) ホホデン゙ョメータ

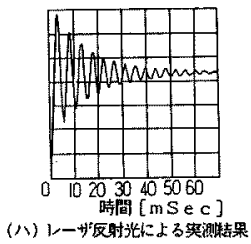

図 12 一相励磁ステップ応答

Fig. 12. Step response at one phase excitation.

〈6・2〉二相励磁のスティフネス特性磁気回路 方程式 ( 8 )とトルク算定式(12)より得られたスティフ ネス特性を図 11 に示す。同図で，ロータ20場合， 実験では測定不能となる範囲があり，これを破線で示 しているが，本解析によってこれがトルクの落込みて あると判明した。二相励磁におけるロー夕平衡位置は $A$ 相小雪極と $B$ 相小歯極が左右に $\pi / 4$ (電気角) 偏 位した位置でバランスしている。この位置を基準とし てロー夕を $\pi / 4$ 変位させると, $A$ 相ではトルクが最 大值に近づき $B$ 相のトルクは 0 となる。更に, $\pi / 4$ 変位させた状態では $B$ 相トルクが増加して行く代わ りに $A$ 相のトルクは減少して行く。この $A$ 相トルク の減少が $B$ 相トルクの增加より大きい場合（一般に ロータの歯幅がステータの歯幅に比べ十分狭い場 合）, ロータ1のようなトルクの落込みが起こるもの と考えられる。

〈6・3〉 一相励磁ステップ応答 図 12 に一相励磁 のステップ応答解析結果とポテンショメータ直結によ る実測およびレーザ反射光による実測結果を示す。ポ
テンショメータ直結法では摩擦による負荷が加わるた め解析值との差が発生する。また，レーザ反射光によ る測定では, シャフト軸に取付けたミラーの反射光を 処理するので，セトリングタイムは正確に測定される が行過ぎ量は不正確である。解析結果は満足し得る一 致を示している。

\section{7.むすび}

本論文ではギャップ部パーミアンスの算出に 0-1 次 境界要素法を応用した二次元磁界解析を用い，モータ の三次元的磁界分布に対しては等価磁気回路を用いる という混合特性解析の手法を提案するものである。

境界要素法を用いることで有限要素法によるよりも 要素数を大幅に隇らすことができ，歯形の形状変化ゃ 位相変化に対し解析が容易となる。

この等価磁気回路では，マグネットと並列に存在す るロータディスク間の漏れ磁束とステータポール部の 漏れ磁束を考慮している。

このような混合解析法の有利な点は実際にモータを 作ることなく，求めるスティフネス特性を有するモー タの設計が容易に行える点や，ロー夕，ステータの歯 形形状を決定したり，マグネットのエネルギー積や寸 法形状の影響を推定できるなどの点にある。

ポール部の磁束測定や二相励磁のスティフネス特 性, 一相励磁ステップ応答の実験結果を通し, 本手法 の有効性が確かめられた。特に二相励磁のスティフネ ス特性では, 従来実験によってトルク特性の不連続性 が見られたが，本手法の解析によってこれがトルクの 落込みであることが判明した。

今後は, 更に精度の高い解析がより短時間で可能な 手法として完成を目指し，また事前に確定した電流変 化を与えながら演算して行く方法から, 諸量を自動的 に処理できる設計手法として，本手法を完成させて行 きたい。また，プルイントルクやプルアウトトルクの 演算も可能な動卜ルク特性の解析システムとしてまと めて行くつもりである。（昭和 63 年 6 月 29 日受付)

\section{文献}

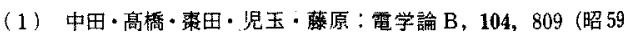
-12)

（2）沢・太田・山㱦・宮垉・留野：電気学会研筫，RM-86-48：SA $-86-41,71$ (昭 61)

（3）石崎：同上, RM-87-85；RM-87-48，127（昭 62)

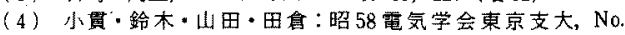
264(昭 58)

（5）山田・小贯・田倉：昭 60 電気学会全大, p.959

(6) Takura, Onuki, Yamada, Amemiya: Proc. International Conference Electrical Machine, 3, 1056 (1986)

(7) Takura, Onuki. Amemiya, Higuchi : Proc. Electric Energy Conference, 1, 321 (1987) 